\title{
Oyster reef restoration supports increased nekton biomass and potential commercial fishery value
}

Austin T Humphries, Megan K La Peyre

Across the globe, discussions centered on the value of nature drive many conservation and restoration decisions. As a result, justification for management activities increasingly asks for two lines of evidence: (1) biological proof of augmented ecosystem function or service, and (2) monetary valuation of these services. For oyster reefs, which have seen significant global declines and increasing restoration work, the need to provide both biological and monetary evidence of reef services on a local-level has become more critical in a time of declining resources. Here, we quantified species biomass and potential commercial value of nekton collected from restored oyster (Crassostrea virginica) reefs in coastal Louisiana over a 3-year period, providing multiple snapshots of biomass support over time. Overall, and with little change over time, fish and invertebrate biomass is $212 \%$ greater at restored oyster reefs than mud-bottom, or $0.12 \mathrm{~kg} \mathrm{~m}^{-2}$. The additional biomass of commercial species is equivalent to an increase of local fisheries value by $226 \%$, or $\$ 0.09 \mathrm{~m}^{-2}$. Understanding the ecosystem value of restoration projects, and how they interact with regional management priorities, is critical to inform local decision-making and provide testable predictions. Quantitative estimates of potential commercial fisheries enhancement by oyster reef restoration such as this one can be used directly by local managers to determine the expected return on investment. 
2 Abstract: Across the globe, discussions centered on the value of nature drive many conservation 3 and restoration decisions. As a result, justification for management activities increasingly asks

4 for two lines of evidence: (1) biological proof of augmented ecosystem function or service, and 5 (2) monetary valuation of these services. For oyster reefs, which have seen significant global 6 declines and increasing restoration work, the need to provide both biological and monetary 7 evidence of reef services on a local-level has become more critical in a time of declining 8 resources. Here, we quantified species biomass and potential commercial value of nekton 9 collected from restored oyster (Crassostrea virginica) reefs in coastal Louisiana over a 3-year 10 period, providing multiple snapshots of biomass support over time. Overall, and with little 11 change over time, fish and invertebrate biomass is $212 \%$ greater at restored oyster reefs than 12 mud-bottom, or $0.12 \mathrm{~kg} \mathrm{~m}^{-2}$. The additional biomass of commercial species is equivalent to an 13 increase of local fisheries value by $226 \%$, or $\$ 0.09 \mathrm{~m}^{-2}$. Understanding the ecosystem value of 14 restoration projects, and how they interact with regional management priorities, is critical to 15 inform local decision-making and provide testable predictions. Quantitative estimates of 16 potential commercial fisheries enhancement by oyster reef restoration such as this one can be 17 used directly by local managers to determine the expected return on investment. 


\section{Introduction}

Millions of people depend on oysters and the reefs they build for income and livelihood (Kirby 2004). While oysters are valued as a fishery commodity, they also provide important ecosystem services, including water quality improvement, shoreline protection, and invertebrate and fish habitat (Breitburg et al., 2000, Cressman et al., 2003; Coen et al., 2007; La Peyre et al., 2014). Nevertheless, reports have indicated a significant global decline in oyster habitat over the last century, with greater than $85 \%$ of historical reefs functionally impaired (Beck et al., 2011). Regional assessments in the US have quantified concomitant loss of oyster biomass to declines in water quality over the same time frame (zu Ermgassen et al., 2013), and calculated the potential value of water filtration and nutrient sequestration provided by oyster reefs (Kellogg et al., 2013; Pollack et al., 2013). Recent work on the role of fringing oyster reefs in shoreline protection suggests reefs may contribute to reduced shoreline retreat rates during high energy storm events (La Peyre et al., 2014). Attempts to relate invertebrate and fish biomass to overall reef extent or characteristics have resulted in contrasting results (Rodney \& Paynter, 2006; Humphries et al., 2011a). General consensus, however, is that understanding the potential role of oyster reefs in enhancing invertebrate and fish habitat requires improving our predictive capacity, and better understanding local context (Lenihan \& Peterson, 1998; Lenihan, 1999; Grabowski et al., 2005).

The net effect of any oyster reef on fish and invertebrate biomass may be highly dependent upon the extent to which the ecological role played by the reef habitat is not redundant in the area (Walker, 1992; Grabowski et al., 2005; Geraldi et al., 2009). Specifically, to what extent do the oyster reefs provide unique recruitment habitat, or spatial refuge from predation, all of which may augment the prey base, increase foraging efficiency for predators, and enhance future productivity (Hixon, 1998; Syms \& Jones, 2000)? Additionally, the long-term effectiveness of oyster reefs to provide ecosystem services is influenced by biological factors such as salinity and water temperature, both of which affect oyster recruitment and growth, or a reef's ability to be self-sustaining and keep up with local sedimentation and subsidence rates (Southworth et al., 2010; Casas, La Peyre \& La Peyre, 2015). This context-dependency is why local values are critical if we want to inform decision-making and understand how restoration efforts may generate benefits supporting local coastal communities.

Broad, large-scale studies are critically valuable in contributing to national and international discussions on the value of restored ecosystems; local studies, however, may lead to more support for local management activities by better framing the issue (Scannel \& Gifford, 2013; Wiest, Raymond \& Clawson, 2015). Furthermore, with broad-scale studies, the oftentimes large range in dollar estimates stresses the inherent variation or uncertainty in values, and is thus difficult to apply to local projects. For example, a recent review of ecosystem services provided by restored oyster reefs within the U.S. compiled quantitative data on water quality services, fish habitat provision, and erosion protection values, and estimated reefs to provide services valued between $\$ 5,500$ and $\$ 99,000$ per hectare per year (Grabowski et al., 2012). Until we explicitly understand what drives these large ranges of values, the need for local assessments of ecosystem provisions is critical and will help to identify where restoration activities will add value.

In this study, we quantify biomass of fishes and invertebrates at six restored oyster reefs in a Louisiana estuary. We use species-specific biomass data to provide a snapshot of biomass support, and estimate enhanced value of commercial fisheries associated with reefs through comparisons with reference sites. As value is subjective, more regional level estimates are 
64

65

66

67

68

69

70

71

72

73

74

75

76

77

78

79

80

81

82

83

84

85

86

87

88

89

90

91

92

93

94

95

96

97

98

99

100

101

102

103

104

105

106

107

108

109

critical in assessing ecosystem services, which often represent the practical scales at which management strategies are designed and implemented.

\section{Materials and Methods}

\section{Ethics Statement}

We obtained all necessary permits for the described study and operated under a scientific collection permit from the Louisiana Department of Wildlife and Fisheries to Dr. Megan La Peyre (S-03-2009, S-105-OYS-2010). No endangered or protected species were collected during this project. Furthermore, fish and invertebrates were collected under the Institutional Animal Care and Use Committee permit 08-005 to Dr. Megan La Peyre through the Louisiana State University Institutional Animal Care and Use Committee.

\section{Study Site}

The study was conducted at Caillou (Sister) Lake, located in Terrebonne Parish, Louisiana $\left(29^{\circ} 14^{\prime} 11.09 \mathrm{~N}, 90^{\circ} 55^{\prime} 16.48 \mathrm{~W}\right.$ ) (Fig. 1). Sister Lake is primarily an open water, brackish system with a mean tidal range of $0.3 \pm 0.03 \mathrm{~m}$ ( \pm one standard error) (LDWF/USGS recorder \# 07381349). Water levels are driven primarily by wind events; dominant winds are typically from the southeast, except during the winter when northerly winds accompany cold fronts.

We selected three regions (North, South, West) within Sister Lake for this study (Fig. 1). Within each region, we chose two sites for reef restoration (\#1, \#2), each with a paired reference mud-bottom treatment (200 m apart). Oyster reefs $(25 \times 1.5 \times 1 \mathrm{~m})$ were constructed in March 2009 with shucked, unaggregated oyster shell (La Peyre et al., 2014). All reefs were placed as close to the shoreline as possible $(5-10 \mathrm{~m})$ and were intertidal; however, due to the low tidal amplitude and water depth within our study area, the reefs were exposed less than $20 \%$ of the time over the study period (La Peyre et al., 2014).

\section{Sampling Procedure}

Water quality variables were taken at each site concurrent with fish and invertebrate sampling which occurred quarterly for 2.5 years, beginning in June of 2009 and ending in October of 2011 ( $2009=3$ sampling events; $2010=4$ sampling events; $2011=3$ sampling events). At each site, we measured temperature $\left({ }^{\circ} \mathrm{C}\right)$, salinity, and dissolved oxygen $\left(\mathrm{mg} \mathrm{L}^{-1}\right)$. Water clarity $(\mathrm{cm})$ was also measured using a Secchi disc at each sampling event.

To characterize fish and invertebrate assemblages, we used a combination of sampling gears including a gill net, bag seine, and plastic substrate trays. We used this range of gears in order to best characterize the entire community that may use the restored oyster reefs. The gill net was intended to characterize the transient fish and invertebrates, and can be defined as those individuals with large home ranges that may feed on or near oyster reefs (Breitburg, 1999). The bag seine was aimed at catching facultative residents that are associated with, and use, the areas adjacent to oyster reefs for either foraging or proximity to refuge. Substrate trays were buried and placed within the shell matrix and intended to quantify resident species, or those living within the shell matrix for refuge or nursery habitat.

At each treatment, a gill net (50 x $1.75 \mathrm{~m}$ with $5,7,10,12,14 \mathrm{~cm}$ monofilament sections) was first deployed to form a semicircular enclosure with the shoreline surrounding the treatment (oyster reef or mud-bottom). The gill net set times averaged $2 \mathrm{hr}$, during which seine and tray 
110 sampling occurred. A bag seine ( $5 \times 2 \mathrm{~m}$ with $3 \mathrm{~mm}$ square delta mesh) was then swept parallel 111 to the shoreline, over mud-bottom, for a distance of $25 \mathrm{~m}$. One sweep was executed on the

112 'shore' side of the treatment, between the treatment and salt marsh vegetation, while one sweep

113 was executed on the "estuary" side of the treatment. Seines were taken to shore where collected

114 nekton were removed and placed in labeled bags on ice for identification in the laboratory.

During reef construction, plastic substrate trays $(63 \times 52 \times 11 \mathrm{~cm})$ lined with $0.5 \mathrm{~mm}$

117 planned sampling events $=180$ trays; sampling without replacement) and at mud-bottom

118 treatments ( 6 mud-bottom treatments $\times 3$ substrate trays $=18$ trays; sampling with replacement).

119 Substrate in the trays matched that of the reef (oyster shell) or reference (mud-bottom)

120 treatments. Plastic substrate trays at oyster reef treatments were randomly sampled by quickly

121 lifting the trays and placing the contents in 3-mm mesh bags. Substrate tray contents were rinsed

122 to remove excess sediment by sieving tray contents on site, and contents placed in labeled bags

123 on ice for identification in the laboratory. After substrate tray removal, substitute oyster cultch

124 was used to fill the hole that was created by removing the tray. Substrate trays at reference

125 treatments (mud-bottom) were anchored in the sediment using PVC poles and sampled with

126 replacement.

127

128

129

After seine and tray samples were taken, the gill net was removed and all nekton were identified, weighed to the nearest $10 \mathrm{~g}$ (wet weight), and total length (TL) measured to the nearest $1 \mathrm{~cm}$ before being released on site. In the laboratory, nekton from seine and substrate tray samples was identified to species or the lowest practical taxon. Individuals of a species in each sample were weighed to the nearest $0.1 \mathrm{~g}$ (wet weight) and measured to the nearest centimeter of TL for fishes and shrimps, or carapace width for crabs. Thirty individuals were randomly subsampled to obtain lengths and weights of individuals from abundant species.

Nekton Biomass and Commercial Fishery Value Calculations

Fish and invertebrate biomass were calculated using the species-level biomass totals from across gear types. Biomass totals at each sample site were divided by that particular reef's area. The same area value that was used to represent the oyster reef was also used for the paired mudbottom treatments. For seine biomass calculations, both seine pulls (in front of, and behind the reef or mud-bottom treatment) were summed to represent a total for that particular treatment area. Tray values were calculated by dividing the biomass of each tray by the area of each tray $\left(0.3276 \mathrm{~m}^{2}\right)$, then scaled to $1 \mathrm{~m}^{2}$. Community-level values were derived by summing all specieslevel biomass at a particular oyster reef or mud-bottom treatment within each shoreline, and then mean and standard error values were calculated from these values to get a sample event (seasonal) mean biomass ( $\mathrm{kg}$ ) per $1 \mathrm{~m}^{2}$. We calculated enhanced biomass as reef biomass minus mud-bottom biomass within each sample period.

Potential commercial fishery value was calculated by multiplying nekton biomass values by the commercial price for a particular species across gear types. Fish and invertebrate prices were derived from the National Marine Fisheries Service commercial landings online database and represented in 2011 US Dollars (http://www.st.nmfs.noaa.gov/commercialfisheries/commercial-landings/annual-landings-with-group-subtotals/index). Species-level commercial fishery values were calculated for mud-bottom and oyster reefs at the sample level, and enhanced values were calculated the same as stated above for nekton biomass (as reef values minus mud-bottom values). Community-level numbers for commercial fish value were derived as described above for fish biomass, by summing all species-level values at treatments within 
156 each shoreline, then mean and standard error values calculated to get a sample event (seasonal)

157 mean commercial fishery value per $1 \mathrm{~m}^{2}$. This approach provides a snapshot of the use of these

158 reefs by commercial fish species; other species such as prey species likely contribute to the

159 commercial fishery value of the reefs, but we assume that this value is integrated through this

160 snapshot approach.

161 We were unable to recover all tray samples due to logistical difficulties and therefore data

162 only exist for one year, or 4 seasons, for resident fauna; a total of 99 substrate trays out of the

163 initial 180 were recovered and sampled (Summer 2009 =23; Fall $2009=31$; Winter 2009 = 25;

164 Spring $2010=13$; Summer $2010=7$ ). This allowed us to calculate resident nekton biomass and

165 commercial fishery value with one year of data; however, to calculate values for the duration of

166 our study, we used these same data for subsequent seasons under the assumption that the reef and

167 mud-bottom treatments would produce at least as much as during the first year of sampling.

168 While this assumption may lead to slightly conservative estimates of nekton biomass, it has been

169 shown in this particular estuary that resident fish and invertebrate biomass at oyster reefs does

170 not increase significantly from one year to the next (Humphries et al., 2011a).

To calculate the cost of constructing the oyster reefs, we used the costs from labor and materials and divided it by the total area of reef created to get a cost per $1 \mathrm{~m}^{2}$. We assumed no

173 costs to maintain reefs.

174

\section{$\underline{\text { Statistical Analyses }}$}

All environmental parameters and nekton data were tested with three-way analysis of variance (ANOVA) where date, region, and treatment were treated as fixed effects. Nekton biomass $\left(\mathrm{kg} \mathrm{m}^{-2}\right)$ was modeled separately for each gear type. Where there were interactions in ANOVAs, we used main effects models with linear contrasts to determine formal relationships. Data were tested for normality using Shapiro-Wilks test and quantile-quantile plots, and no transformations were necessary.

We analyzed nekton taxa individually to evaluate treatment effects on the most common species, i.e. species that were more than $3 \%$ of the total catch. We used individual pairwise ttests to compare each species' mean overall biomass between the paired oyster reef and mudbottom treatments.

We modeled nekton biomass and commercial fishery values separately with one-way ANOVAs and linear regression, using date as the fixed effect. Normality of data was assessed using quantile-quantile plots. All statistical analyses were done in R, version 3.1.3 (R Core Development Team, 2015).

\section{Results}

\section{Environmental Variables}

Temperature and dissolved oxygen mean and variation showed typical seasonal patterns and were not significantly different among regions or treatment at any date (Table 1). Mean daily water temperature was $23.8^{\circ} \mathrm{C}( \pm 0.4)$ and ranged between 5 and $35^{\circ} \mathrm{C}$, and mean dissolved oxygen was $7.6 \mathrm{mg} \mathrm{L}^{-1}( \pm 0.1)$ and ranged between 2 and $16 \mathrm{mg} \mathrm{L}^{-1}$ throughout the experiment. Salinity was greater at the South region during all years $(\mathrm{p}<0.5)$ with a mean of $13.1( \pm 0.6)$ as compared to means of $9.5( \pm 0.5)$ (West) and $10.2( \pm 0.6)$ (North), with an overall range of 0 to 
224

225

226

227

228

229

230

231

232

233

234

235

236

237

238

239

240

241

242

243

244

245

246

$47.6 \mathrm{~cm} \mathrm{( \pm 1.9)} \mathrm{as} \mathrm{compared} \mathrm{to} \mathrm{means} \mathrm{of} 38.7 \mathrm{~cm}(1.6)$ (West) and $41.3 \mathrm{~cm} \mathrm{(2.1)} \mathrm{(North)} \mathrm{and}$ overall ranged between 10 and $70 \mathrm{~cm}$.

Nekton Biomass

In 120 gill net samples a total of 1,805 individuals from 32 species, resulting in $749.28 \mathrm{~kg}$ were collected . Oyster reefs had a mean biomass of $0.155( \pm 0.019) \mathrm{kg} \mathrm{m}^{-2}$, and mud-bottom was $0.09( \pm 0.018) \mathrm{kg} \mathrm{m}^{-2}$. In 240 seine samples, a total of 17,968 individuals were collected that represented 54 species and $14.86 \mathrm{~kg}$ total, with a mean biomass of $0.001( \pm 0.001) \mathrm{kg} \mathrm{m}^{-2}$ at both oyster reefs and mud-bottom. The 99 tray samples resulted in $1.33 \mathrm{~kg}$ of fish and invertebrate biomass from 1,592 individuals and 21 total species. Oyster reefs had a mean biomass of 0.05 ( \pm $0.08) \mathrm{kg} \mathrm{m}^{-2}$, whereas mud-bottom was $0.008( \pm 0.002) \mathrm{kg} \mathrm{m}^{-2}$.

ANOVA results from the gill net (transients) and tray data (residents) showed a significant treatment and date effect (Table 2, Figure 2). Individual contrasts indicated that gill nets on oyster reefs in Fall 2010 and Spring 2011 had significantly higher biomass values than mud-bottom reference sites. All comparisons for tray data between oyster reefs and mud-bottom sites were statistically significant . ANOVA results for the seine data were all non-significant except for date .

All species except Northern puffer (Sphoeroides maculatus) collected in gill nets had higher biomass at oyster reefs than mud-bottom (Table 3, Fig. 3). However, only sheepshead (Archosargus probatocephalus) was statistically significant $(\mathrm{p}<0.01)$. In seines, no species showed significant differences in pairwise t-tests, although Gulf menhaden (Brevoortia patronus), brown shrimp (Penaeus aztecus), blue crab (Callinectes sapidus), and bay anchovy (Anchoa mitchilli) all had higher biomass values at oyster reefs. All species except blue crab had higher biomass at oyster reefs in tray samples, and four species were statistically significant: speckled eel (Myrophis punctatus), mud crab (Panopeus herbstii), naked goby (Gobiosoma bosc), and freckled blenny (Hypsoblennius ionthas) $(\mathrm{p}<0.05)$. One exception to this trend was the blue crab, which had greater biomass at mud-bottom $(\mathrm{p}<0.01)$.

Nekton biomass at oyster reefs was $212 \%$ greater than at mud-bottom, or $0.122( \pm 0.039)$ $\mathrm{kg} \mathrm{m}^{-2}$ (Table 4). The potential for oyster reefs to increase nekton biomass was positive in all sampling periods except one (Fig. 4a). The linear model, however, was not statistically significant $(F=1.133$, $p$-value $=0.358)$ and had an $r$-squared value of 0.169 , with an intercept of 0.11 and slope of -0.003 .

\section{Commercial Fishery Value}

Commercial fish prices of species captured ranged from $\$ 0$ to $\$ 4.53 \mathrm{~kg}^{-1}$ (2011 dollars; Table 3). Species that contributed most to augmenting the potential commercial fishery value surrounding restored oyster reefs were sheepshead, spotted seatrout (Cynoscion nubulosus), Southern flounder (Paralichthys lethostigma), and bull shark (Carcharhinus leucas), all of which were caught with gill nets (Table 2).

Potential commercial fishery value at oyster reefs was more than double than at mudbottom, or $\$ 0.09( \pm \$ 0.06) \mathrm{m}^{-2}$ (Table 4). The potential for oyster reefs to increase the local commercial fishery value was positive in all sampling periods except two (Fig. 4b). The linear model was statistically significant $(\mathrm{F}=2.208$, $\mathrm{p}$-value $=0.037)$ and had an $\mathrm{r}$-squared value of 0.284 , with an intercept of -0.003 and slope of 0.02 .

The cost to build all the reefs in 2009 was $\$ 23,545.23$ (or $\$ 24,686.84$ in 2011 dollars). With a total reef area of $235 \mathrm{~m}^{2}$, this equates to approximately $\$ 105.03$ to build $1 \mathrm{~m}^{2}$ of reef with 
272

273

274

275

276

277

278

279

280

281

282

283

284

285

286

287

288

289

290

291

292

unaggregated oyster shell (Table 4). This is a one-time, initial cost, and we assume no maintenance is necessary for these reefs to persist and be self-sustaining because of high recruitment and low oyster mortality rates on these reefs (La Peyre et al., 2014).

\section{Discussion}

The restored oyster reefs provided increased biomass of nekton and supported augmented commercial fisheries value. In both cases, the reefs more than doubled the provision of the service as compared to reference sites. In real numbers, the actual augmentation values were relatively low $\left(0.12 \mathrm{~kg} \mathrm{~m}^{-2}, \$ 0.09 \mathrm{~m}^{-2}\right)$. This likely reflects reef location within a complex of extensive oyster beds and productive coastal marsh (Grabowski et al., 2005), highlighting the need to understand the local context of any restoration project. Further analyses to quantify recreational fishery value and other provided ecosystem services would contribute to more complete analyses of local reef restoration benefits.

The hypothesis that restoration of estuarine habitats may increase nekton biomass and commercial fishery value relies on the assumption that either quality or quantity of habitat is limiting (Turner et al., 2000). For oysters, restoration studies often assume reef or structured habitat is limiting because of global declines in functional oyster reef habitat (Peterson, Grabowski \& Powers, 2003; Beck et al., 2011; Grabowski et al., 2012). However, due to a lack of historical and current data, it is unclear if Louisiana suffers significant declines of oyster habitat. Furthermore, our study area has been a public oyster seed reservation since 1940, and almost $30 \%$ of the bottom in the area is classified as oyster beds (Louisiana Department of Wildlife and Fisheries, 2011). Despite the extensive oyster reef habitat in the area, and the productive salt marshes surrounding our created reefs, our data still capture an overall increase in nekton biomass. This finding suggests that either fish and invertebrate biomass still remains limited by habitat availability despite the extensive reefs already present, or that nekton may be limited by the quality or characteristics of the habitat available.

Although vegetated habitats and oyster reefs are not functionally equivalent, they may provide similar services (Geraldi et al., 2009). For instance, we found that the restored oyster reefs did not affect facultative resident species, or individuals that are potentially using the reef during an ontogenetic shift. It is possible that while the reefs provided added structural habitat, the marginal effect was relatively low to the adjacent marsh edges. In fact, our restored reefs and reference sites were all adjacent to marsh edge habitat, which has been shown to provide valuable habitat for numerous similar nekton species (Stunz, Minello \& Rozas, 2010). Within the marsh and shallow water estuarine complexes of coastal Louisiana, determining which habitats may limit or support organisms can be difficult (Baltz, Racocinski \& Fleeter, 1993; Chesney, Baltz \& Thomas, 2000).

Habitat quality affects species use. For oyster reefs, quality may be considered as reef size, height, and material base, all of which have been shown to influence ecosystem services (Lenihan, 1999; Lenihan et al., 2001). These structural characteristics may explain the increase in resident fish and invertebrate species biomass we observed in this study. For example, the existing reef system in our study area consists predominantly of flat, harvested subtidal structures, while our restored reefs were three-dimensional intertidal habitats. The difference in habitat morphology is potentially driving species use (Humphries et al., 2011a), and our results further corroborate this hypothesis. A caveat to this, however, is that our restored reefs provided immediate support of nekton biomass, which did not significantly increase over time. This is 
293

294

295

296

297

298

299

300

301

302

303

304

305

306

307

308

309

310

311

312

313

314

315

316

317

318

319

320

321

322

323

324

325

326

327

328

329

330

331

332

333

334

335

336

337

338

despite significant increases in structural complexity via recruitment and growth of oysters (Casas, La Peyre \& La Peyre, 2015). This finding suggests that simply the existence of threedimensional structure, and the lack of hard bottom rather than any reef characteristics may be a limiting factor.

The immediate support of higher nekton biomass on the reefs as compared to mudbottom habitat suggests that the higher reef biomass initially resulted from a shift in the local population from surrounding habitats. In restoring habitats for nekton, the question of whether the new habitat is simply attracting individuals from the local populations, or actually enhancing production remains key, and difficult in valuing the restored habitat (e.g. Grossman, Jones \& Seaman, 1997; NOAA 1997). Generally, evidence for enhancement of production involves determining whether the restored habitat provides habitat that limits species recruitment, and secondly, whether new reefs provide spatial refuge from predation and increased prey resources (i.e. Powers et al., 2003; Peterson, Grabowski \& Powers, 2003). Previous work has assumed that species with enhanced recruits on reefs relative to reference sediments are limited by current reef area (Powers et al., 2003; Peterson, Grabowski \& Powers, 2003). While our sampling documented a range of resident and transient fish sizes, few recruit-sized individuals were captured in either the reef or the mud-bottom. However, if the reef provides enhanced reefassociated prey resources, as indicated by our data with the increased resident species biomass, it would support the contention that the reef is enhancing fish production, not through the addition of fish to the local population, but by increasing survival and enhancing growth of individuals already in the regional population. Enhanced densities of fish (transient, resident of all size classes) thus reflect positive impacts of the reef on survival (Powers et al., 2003). For resident species specifically, which generally have small home ranges (Teo \& Able, 2003; Potthoff \& Allen, 2003), the assumption would be that this new habitat offered better refuge from predation (Hixon, 1998; Humphries et al. 2011b), resulting in enhanced survival, and thus production.

Our restored oyster reefs were estimated to provide the local commercial fishery with $\$ 0.17 \mathrm{~m}^{-2}$. This value failed to cover the costs of construction within the three years of monitoring. Other studies have reported higher values (e.g. $\$ 0.41 \mathrm{~m}^{-2}$ by Grabowski et al., 2012) however, the differences in numbers likely reflect location- or region-specific effects of reefs, as it is difficult to transfer values from ecosystem services out of their original context or region (Turner et al., 2003). Additionally, black (Pogonias cromis) and red drum (Sciaenops ocellatus) contributed 0.03 and $0.01 \mathrm{~kg} \mathrm{~m}^{-2}$, respectively, to the overall increased nekton biomass value of $0.12 \mathrm{~kg} \mathrm{~m}^{-2}$. These two drum have no commercial value in Louisiana, but high recreational value which is significant in the area. For instance, in 2006, the recreational fishery value in coastal Louisiana was estimated to augment local economies by over $\$ 750$ million and support nearly 8,000 jobs (Coastal Restoration and Protection Authority of Louisiana, 2012). Overall, however, this means that only $34 \%$ of the nekton biomass was factored into the calculation of commercial fishery value. Given the high value of recreational fishing in many coastal areas, developing methods to include their value would contribute to more accurate valuation of reef services.

Alone, the potential increased commercial fishery value of the restored oyster reefs fail to cover the costs of construction within a three-year time frame. This snapshot approach using biomass fails to capture actual production support, which would include accounting for recruitment and future reef productivity (Peterson, Grabowski \& Powers, 2003). As a result, these results likely underestimate the full value of the reef. Additionally, full valuation of restoration activities could include other services such as shoreline protection, recreational fisheries enhancement and water quality improvements, which have been estimated to be as 
much as $\$ 17,836$ per hectare (Grabowski et al., 2012). The valuation of services and relative value of different functions likely varies greatly between locales and regions. Given the land loss and hypoxia issues coastal Louisiana faces, other services such as shoreline protection and water quality improvement may provide a higher valuation estimate in comparison to other regions.

\section{Acknowledgements}

We thank P. Yakupzack, C. Duplechain, G. Decossas, S. Miller, A. Catalenello, S. Beck, T. Mace, L. Broussard, S. Hein, P. Banks, H. Finley, S. Casas-Liste, J. Gordon, J. La Peyre, L. Schwarting, A. Honig, and B. Eberline for providing logistical, field, and laboratory assistance. Thanks to M. Voisin and Motivatit Oysters for providing oyster shell. We also thank J. Grabowski, M. Griffin, and 2 anonymous reviewers for making comments that greatly improved earlier versions of the manuscript. Any use of trade, product, or firm names is for descriptive purposes only and does not imply endorsement by the U.S. Government.

\section{References}

Baltz DM, Rakocinski C, Fleeger JW. 1993. Microhabitat use by marsh-edge fishes in a Louisiana estuary. Environmental Biology of Fishes 36:109-126.

Beck MW, Brumbaugh RD, Airoldi L, Carranza A, Coen LD, Crawford C, Defeo O, Edgar GJ, Hancock B, Kay MC. 2011. Oyster reefs at risk and recommendations for conservation, restoration, and management. Bioscience 61:107-116.

Breitburg D. 1999. Are 3-dimensional structure and healthy oyster populations the keys to an ecologically interesting and important fish community? Oyster reef habitat restoration: a synopsis and synthesis of approaches. Virginia Institute of Marine Science Press, Williamsburg, VA pp.238-249.

Breitburg DL, Coen LD, Luckenbach MW, Mann R, Posey M, Wesson JA. 2000. Oyster reef restoration: convergence of harvest and conservation strategies. Journal of Shellfish Research 19:371-377.

Casas SM, La Peyre J, La Peyre MK. 2015. Restoration of oyster reefs in an estuarine lake: population dynamics and shell accretion. Marine Ecology Progress Series 524:171-184

Chesney EJ, Baltz DM, Thomas G. 2000. Louisiana estuarine and coastal fisheries and habitats: perspectives from a fish's eye view. Ecological Applications 10:350-366.

CPRA, Coastal Restoration and Protection Authority of Louisiana. 2012. Louisiana's Comprehensive Master Plan for a Sustainable Coast. Accessed online 4/20/2015 at http://coastal.la.gov/a-common-vision/2012-coastal-master-plan/

Coen LD, Brumbaugh RD, Bushek D, Grizzle R, Luckenbach MW, Posey MH, Powers SP, Tolly SG. 2007. Ecosystem services related to oyster restoration. Marine Ecology Progress Series 341:303-307.

Cressman KA, Posey MH, Mallin MA, Leonard LA, Alphin TD. 2003. Effects of oyster reefs on water quality in a tidal creek estuary. Journal of Shellfish Research 22:753-762

Geraldi NR, Powers SP, Heck KL, Cebrian J. 2009. Can habitat restoration be redundant? Response of mobile fishes and crustaceans to oyster reef restoration in marsh tidal creeks. Marine Ecology Progress Series 389:171-180.

Grabowski JH, Brumbaugh RD, Conrad RF, Keeler AG, Opaluch JJ, Peterson CH, Piehler MF, Powers SP, Smyth AR. 2012. Economic valuation of ecosystem services provided by oyster reefs. Bioscience 62:900-909. 
385

386

387

388

389

390

391

392

393

394

395

396

397

398

399

400

401

402

403

404

405

406

407

408

409

410

411

412

413

414

415

416

417

418

419

420

421

422

423

424

425

426

427

428

Grabowski JH, Hughes AR, Kimbro DL, Dolan MA. 2005. How habitat setting influences restored oyster reef communities. Ecology 86:1926-1935.

Grossman GD, Jones GP, Seaman WJ Jr. 1997. Do artificial reefs increase regional fish production? A review of existing data. Fisheries Management 22:17-23.

Hixon MA. 1998. Population dynamics of coral-reef fishes: Controversial concepts and hypotheses. Australian Journal of Ecology 23:192-201.

Humphries AT, La Peyre MK, Kimball ME, Rozas LP. 2011a. Testing the effect of habitat structure and complexity on nekton assemblages using experimental oyster reefs. Journal of Experimental Marine Biology and Ecology 402:172-179.

Humphries AT, La Peyre MK, Decossas GA. 2011b. The Effect of Structural Complexity, Prey Density, and "Predator-Free Space" on Prey Survivorship at Created Oyster Reef Mesocosms. PLOS ONE 6(12): e28339.

Kellogg ML, Cornwell JC, Owens MS, Paynter KT. 2013. Denitrification and nutrient assimilation on a restored oyster reef. Marine Ecology Progress Series 480:1-19.

Kirby MX. 2004 Fishing down the coast: Historical expansion and collapse of oyster fisheries along continental margins. Proceedings of the National Academy of Sciences of the United States of America 101:13096-13099.

La Peyre MK, Humphries AT, Casas SM, La Peyre JF. 2014 Temporal variation in development of ecosystem services from oyster reef restoration. Ecological Engineering 63:34-44.

Lenihan HS. 1999. Physical-biological coupling on oyster reefs: How habitat structure influences individual performance. Ecological Monographs 69:251-275.

Lenihan HS, Peterson CH. 1998. How habitat degradation through fishery disturbance enhances impacts of hypoxia on oyster reefs. Ecological Applications. 8:128-140.

Lenihan HS, Peterson CH, Byers JE, Grabowski JH, Thayer GW, Colby DR. 2001. Cascading of habitat degradation: Oyster reefs invaded by refugee fishes escaping stress. Ecological Applications 11:764-782.

LDWF, Louisiana Department of Wildlife and Fisheries. 2011. Oyster stock assessment report of the public oyster areas in Louisiana. Oyster Data Report Series \#17. http://www.wlf.louisiana.gov/sites/default/files/pdf/document/37757-stockassessments/2010 oyster stock assessment.pdf.

NOAA (National Oceanographic and Atmospheric Administration). 1997. Habitat equivalency analysis: an overview. Policy and Technical Paper Series. No. 95-1. Damage Assessment and Restoration Program, NOAA. Silver Spring, MD.

Peterson CH, Grabowski JH, Powers SP. 2003. Estimated enhancement of fish production resulting from restoring oyster reef habitat: quantitative valuation. Marine Ecology Progress Series 264:249-264.

Pollack JB, Yoskowitz D, Kim HC, Montagna PA. 2013. Role and value of nitrogen regulation provided by oysters (Crassostrea virginica) in the Mission-Aransas Estuary, Texas, USA. PLOS ONE 8:e65314.

Potthoff MT, Allen DM. 2003. Site fidelity, home range, and tidal migrations of juvenile pinfish, Lagodon rhomboides, in salt marsh creeks. Environmental Biology of Fishes 67: 231-240.

R Core Development Team. 2015. R version 3.1.3. R Project for Statistical Computing Vienna, Austria. 
Rodney WS, Paynter KT. 2006. Comparisons of macrofaunal assemblages on restored and nonrestored oyster reefs in mesohaline regions of Chesapeake Bay in Maryland. Journal of Experimental Marine Biology and Ecology 335:39-51.

Scannell L, Gifford R. 2013. Personally relevant climate change: the role of place attachment and local versus global message framing in engagement. Environmental Behavior 45:6085.

Southworth M, Harding JM, Wesson JA, Mann R. 2010. Oyster (Crassostrea virginica, Gmelin 1791) population dynamics on public reefs in the Great Wicomico River, Virginia, USA. Journal of Shellfish Research 29:271-290.

Stunz G, Minello T, Rozas L. 2010. Relative value of oyster reef as habitat for estuarine nekton in Galveston Bay, Texas. Marine Ecology Progress Series 406:147-159.

Syms C, Jones GP. 2000. Disturbance, habitat structure, and the dynamics of a coral reef fish community. Ecology 81:2714-2729.

Teo SLH, Able KW. 2003. Growth and production of the mummichog (Fundulus heteroclitus) in a restored salt marsh. Estuaries 26: 51-63.

Turner RK, Paavola J, Cooper P, Farber S, Jessamy V, Georgiou S. 2003. Valuing nature: lessons learned and future research directions. Ecological Economics 46:493-510.

Turner RK, Van Den Bergh JC, Vunderqvist T, Barendregt A, van der Straaten J, Maltby E, van Ierland EC. 2000. Ecological-economic analysis of wetlands: scientific integration for management and policy. Ecological Economics 35:7-23.

Walker BH. 1992. Biodiversity and ecological redundancy. Conservation Biology 6:18-23.

Wiest SL, Raymond L, Clawson RA. 2015. Framing, partisan predispositions, and public opinion on climate change. Global Environmental Change 31:187-198.

zu Ermgassen PS, Spalding MD, Grizzle RE, Brumbaugh RD. 2013. Quantifying the loss of a marine ecosystem service: filtration by the eastern oyster in US estuaries. Estuaries and Coasts 36:36-43. 


\section{Table $\mathbf{1}$ (on next page)}

\section{Environmental parameters}

Mean ( \pm standard error) of discrete water quality samples collected at each site during each sample event $(n=627)$. Letters after means indicate significant differences between regions within years $(p<0.05)$. 
2 Table 1. Mean ( \pm standard error) of discrete water quality samples collected at each site during each sample event $(\mathrm{n}=627)$. Letters 3 after means indicate significant differences between regions within years $(p<0.05)$.

\begin{tabular}{|c|c|c|c|c|c|c|c|c|c|}
\hline & \multicolumn{3}{|l|}{ Year 1} & \multicolumn{3}{|l|}{ Year 2} & \multicolumn{3}{|l|}{ Year 3} \\
\hline & North & South & West & North & South & West & North & South & West \\
\hline Temperature $\left({ }^{\circ} \mathrm{C}\right)$ & $26.4(0$ & $24.8(0.8)$ & $25.1(0.7)$ & $24.1(1.3)$ & $23.2(1.3)$ & $23.3(1.4)$ & $22.9(1.1)$ & $22.5(1.3)$ & $22.3(1.4)$ \\
\hline Dissolved Oxygen $\left(\mathrm{mg} \mathrm{L}^{-1}\right)$ & $7.5(0.2)$ & $7.4(0.3)$ & $7.4(0.2)$ & $6.7(0.4)$ & $6.4(0.4)$ & $7.6(0.6)$ & $8.2(0.4)$ & $8.5(0.6)$ & $8.9(0.5)$ \\
\hline Salinity & $9.3(0.6)^{a}$ & $13.3(0.7)^{b}$ & $8.9(0.7)^{a}$ & $9.5(0.7)^{\mathrm{a}}$ & $12.1(0.6)^{b}$ & $\mathrm{~b} 9(0.7)^{\mathrm{a}}$ & $11.7(0.9)$ & $13.9(1.1)$ & $11.1(0.9)$ \\
\hline Secchi Depth (cm) & $35(2.1)^{\mathrm{a}}$ & $42.4(2.2)^{\mathrm{b}}$ & $37.1(1.3)^{\mathrm{a}}$ & $47.9(2.6)^{\mathrm{a}}$ & $49(1.6)^{a}$ & $36.1(2.3)^{\mathrm{b}}$ & $41.8(2.4)^{\mathrm{a}}$ & $55.1(3.6)^{b}$ & $47(2.3)^{a}$ \\
\hline
\end{tabular}

5 


\section{Table 2 (on next page)}

Statistical results

Results from three-way analysis of variance (ANOVA) on nekton biomass data. Treatment refers to reef and mud-bottom habitat. Bold values indicate statistical significance at the $p<$ 0.05 level. 
2 Table 2. Results from three-way analysis of variance (ANOVA) on nekton biomass data.

3 Treatment refers to reef and mud-bottom habitat. Bold values indicate statistical significance at

4 the $\mathrm{p}<0.05$ level.

5

\begin{tabular}{llll}
\hline Gill net & Df & $F$ & $p$-value \\
\hline Date & 9 & 2.155 & $\mathbf{0 . 0 3 9}$ \\
Region & 2 & 2.068 & 0.089 \\
Treatment & 1 & 8.002 & $\mathbf{0 . 0 0 6}$ \\
Date x Region & 18 & 1.566 & 0.100 \\
Date $\times$ Treatment & 9 & 1.134 & 0.354 \\
Region x Treatment & 2 & 2.329 & 0.091 \\
Date x Region x Treatment & 18 & 1.167 & 0.317 \\
\hline
\end{tabular}

6

\begin{tabular}{llll}
\hline Seine & Df & $\mathrm{F}$ & $\mathrm{p}$-value \\
\hline Date & 9 & 4.349 & $<\mathbf{0 . 0 0 1}$ \\
Region & 2 & 0.435 & 0.650 \\
Treatment & 1 & 0.004 & 0.949 \\
Date $\times$ Region & 18 & 0.802 & 0.690 \\
Date $\times$ Treatment & 9 & 0.725 & 0.684 \\
Region $\times$ Treatment & 2 & 0.495 & 0.612 \\
Date $x$ Region $x$ Treatment & 18 & 0.579 & 0.901 \\
\hline
\end{tabular}

7

\begin{tabular}{llll}
\hline Tray & Df & $\mathrm{F}$ & $\mathrm{p}$-value \\
\hline Date & 3 & 4.221 & $\mathbf{0 . 0 2 1}$ \\
Region & 2 & 1.936 & 0.175 \\
Treatment & 1 & 20.243 & $<\mathbf{0 . 0 0 1}$ \\
Date x Region & 6 & 0.455 & 0.832 \\
Date $\times$ Treatment & 3 & 1.725 & 0.200 \\
Region x Treatment & 2 & 1.794 & 0.196 \\
Date x Region x Treatment & 3 & 0.778 & 0.523 \\
\hline
\end{tabular}

8

9 


\section{Table 3 (on next page)}

Nekton species captured in study

Mean ( \pm one standard error) increased nekton biomass $\left(\mathrm{kg} \mathrm{m}^{-2}\right.$ ), commercial fish price ( $\$$ $\left.\mathrm{kg}^{-1}\right)$, and increased value of commercial fishery $\left(\$ \mathrm{~m}^{-2}\right)$ by species and gear type from experimental oyster reef versus paired reference mud-bottom sites. Only dominant species (i.e. > 3\% of total biomass) are presented. Negative values indicate mud-bottom references sites had a greater value for that particular year. All currency is in 2011 US dollars. 
Table 3. Mean ( \pm one standard error) increased nekton biomass $\left(\mathrm{kg} \mathrm{m}^{-2}\right)$, commercial fish price $\left(\$ \mathrm{~kg}^{-1}\right)$, and increased value of commercial fishery $\left(\$ \mathrm{~m}^{-2}\right)$ by species and gear type from experimental oyster reef versus paired reference mud-bottom sites. Only dominant species (i.e. $>3 \%$ of total biomass) are presented. Negative values indicate mud-bottom references sites had a greater value for that particular year. All currency is in 2011 US dollars.

\begin{tabular}{|c|c|c|c|c|c|c|c|c|c|}
\hline \multirow[b]{2}{*}{ Gear } & \multirow[b]{2}{*}{ Species } & \multirow{2}{*}{$\begin{array}{c}\text { Common } \\
\text { name }\end{array}$} & \multicolumn{3}{|c|}{ Increased biomass (kg m $\left.\mathbf{~ m}^{-2}\right)$} & \multirow{2}{*}{$\begin{array}{c}\text { Commerci } \\
\text { al fish } \\
\text { price } \\
\left(\$ \mathbf{k g}^{-1}\right)\end{array}$} & \multicolumn{3}{|c|}{ Increased fishery value $\left(\$ \mathrm{~m}^{-2}\right)$} \\
\hline & & & Year 1 & Year 2 & Year 3 & & Year 1 & Year 2 & Year 3 \\
\hline \multirow{24}{*}{$\begin{array}{l}\text { Gill } \\
\text { net }\end{array}$} & Archosargus & & 0.0216 & 0.0106 & 0.0334 & & 0.027 & 0.013 & 0.042 \\
\hline & probatocephalus & Sheepshead & $(0.0144)$ & $(0.0096)$ & $(0.0117)$ & 1.26 & $(0.018)$ & $(0.012)$ & $(0.015)$ \\
\hline & & Hardhead & 0.0006 & 0.0108 & 0.0051 & & 0.001 & 0.011 & 0.005 \\
\hline & Arius felis & $\begin{array}{l}\text { catfish } \\
\text { Gafftonsail }\end{array}$ & $\begin{array}{l}(0.0051) \\
-0.0033\end{array}$ & $\begin{array}{c}(0.0068) \\
0.0023\end{array}$ & $(0.0064)$ & 1.05 & $\begin{array}{l}(0.005) \\
-0.003\end{array}$ & $(0.007)$ & \\
\hline & Bagre marinus & catfish & $\begin{array}{l}-0.0033 \\
(0.0026)\end{array}$ & $\begin{array}{c}0.0023 \\
(0.0053)\end{array}$ & $\begin{array}{c}0.0001 \\
(0.0003)\end{array}$ & 1.05 & $\begin{array}{l}-0.003 \\
(0.003)\end{array}$ & $\begin{array}{l}0.002 \\
(0.006)\end{array}$ & $0(0)$ \\
\hline & & & 0.0072 & 0.0003 & 0.0005 & & 0.001 & & \\
\hline & Brevoortia patronus & Gulf menhaden & $(0.0037)$ & $(0.0005)$ & $(0.0003)$ & 0.17 & $(0.001)$ & $0(0)$ & $0(0)$ \\
\hline & & & -0.0003 & 0.0007 & & & -0.001 & 0.001 & \\
\hline & Callinectes sapidus & Blue crab & $(0.0009)$ & $(0.0006)$ & $0(0)$ & 2.01 & $(0.002)$ & $(0.001)$ & $0(0)$ \\
\hline & Caranx hippos & Crevalle jack & $0(0)$ & $0(0)$ & $\begin{array}{l}-0.0008 \\
(0.0005)\end{array}$ & 2.02 & $0(0)$ & $0(0)$ & $\begin{array}{l}-0.002 \\
(0.001)\end{array}$ \\
\hline & & & 0.0223 & 0.0151 & -0.0148 & & & 0.027 & -0.027 \\
\hline & Carcharhinus leucas & Bull shark & $(0.0139)$ & $(0.0089)$ & $(0.0149)$ & 1.80 & $0.04(0.025)$ & $(0.016)$ & $(0.027)$ \\
\hline & & Atlantic & 0.0002 & 0.0008 & 0.0004 & & & & \\
\hline & Chaetodipterus faber & spadefish & $(0.0002)$ & $(0.0006)$ & $(0.0003)$ & 0.16 & $0(0)$ & $0(0)$ & $0(0)$ \\
\hline & & Spotted & 0.0032 & -0.0026 & 0.0165 & & 0.014 & -0.012 & 0.075 \\
\hline & Cynoscion nebulosus & seatrout & $(0.0024)$ & $(0.0034)$ & $(0.0075)$ & 4.53 & $(0.011)$ & $(0.016)$ & $(0.034)$ \\
\hline & & & & 0.0012 & & & & 0.001 & \\
\hline & Dasyatis sabina & Atlantic stingray & $0(0)$ & $(0.0012)$ & $0(0)$ & 0.45 & $0(0)$ & $(0.001)$ & $0(0)$ \\
\hline & Dorosoma cepedianum & Gizzard shad & $0(0)$ & $\begin{array}{l}-0.0001 \\
(0.0003)\end{array}$ & $\begin{array}{l}-0.0003 \\
(0.0008)\end{array}$ & 1.74 & $0(0)$ & $0(0.001)$ & $0(0.001)$ \\
\hline & & & 0.0007 & 0.0001 & & & & & \\
\hline & Elops saurus & Ladyfish & $(0.0007)$ & $(0.0011)$ & $\begin{array}{c}0.0006(0.001) \\
-0.0001\end{array}$ & 0.00 & $0(0)$ & $0(0)$ & $0(0)$ \\
\hline & Lagodon rhomboides & Pinfish & $0(0)$ & $0(0)$ & $(0.0001)$ & 1.29 & $0(0)$ & $0(0)$ & $0(0)$ \\
\hline & Leiostomus xanthurus & Spot & $\begin{array}{c}0.0001 \\
(0.0001)\end{array}$ & $0(0.0001)$ & $0(0)$ & 1.84 & $0(0)$ & $0(0)$ & $0(0)$ \\
\hline & Micropogonias undulatus & Atlantic croaker & 0.0022 & 0.0002 & -0.0004 & 1.67 & 0.004 & $0(0.001)$ & -0.001 \\
\hline
\end{tabular}




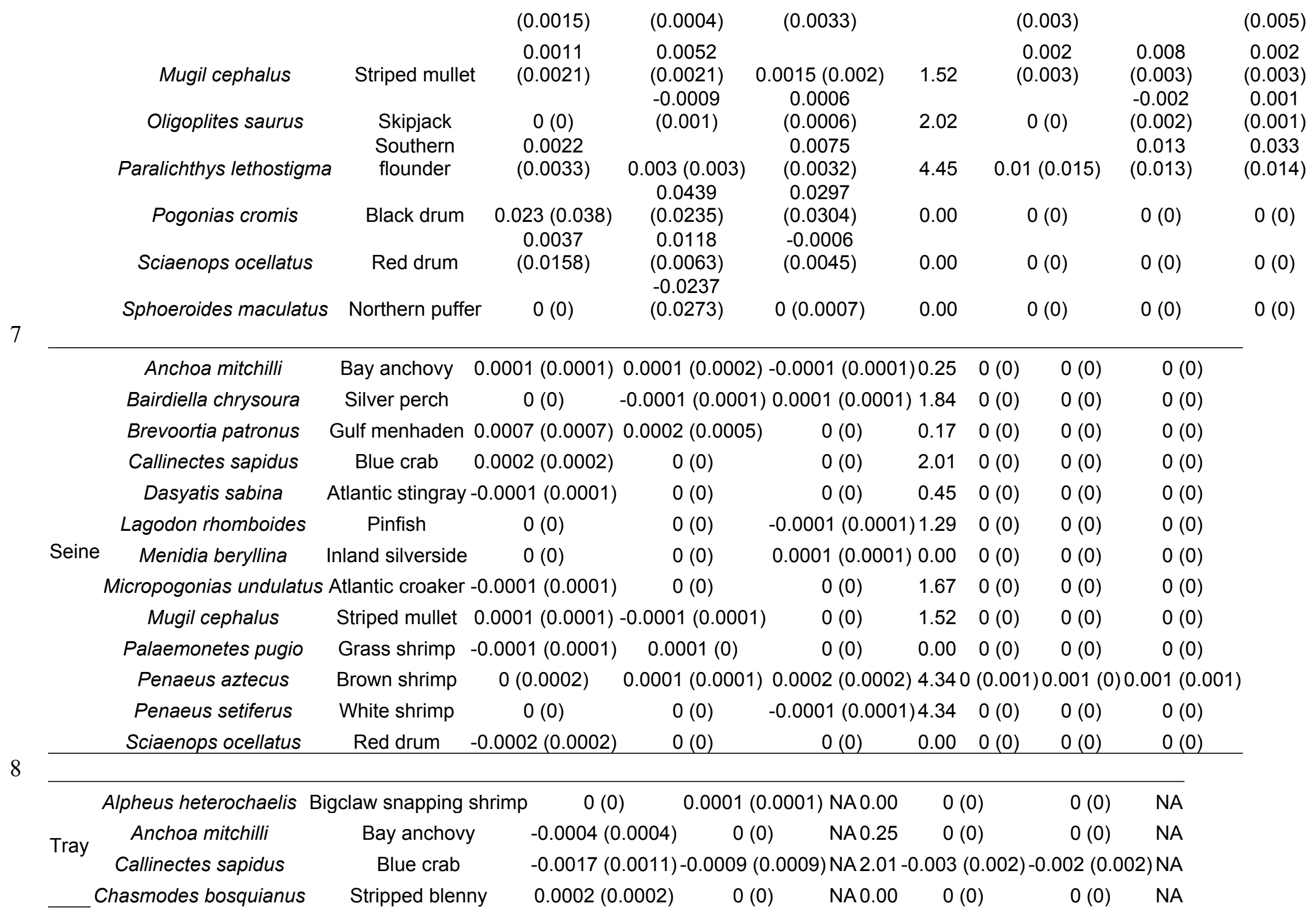




\begin{tabular}{|c|c|c|c|c|c|c|c|}
\hline Cynoscion nebulosus & Spotted seatrout & $-0.0004(0.0004)$ & $0(0)$ & \multicolumn{2}{|c|}{ NA4.53-0.002 (0.002) } & $0(0)$ & NA \\
\hline Gobiesox strumosus & Skilletfish & $0.0031(0.0014)$ & $0(0)$ & NA 0.00 & $0(0)$ & $0(0)$ & NA \\
\hline Gobiosoma bosc & Naked goby & $0.0046(0.0015)$ & $0.0011(0.0011)$ & ) NA 0.00 & $0(0)$ & $0(0)$ & NA \\
\hline Hypsoblennius ionthas & Freckled blenny & $0.0053(0.0027)$ & $0.0003(0.0003)$ & NA 0.00 & $0(0)$ & $0(0)$ & NA \\
\hline Mugil cephalus & Striped mullet & $-0.0001(0.0001)$ & $0(0)$ & NA 1.52 & $0(0)$ & $0(0)$ & NA \\
\hline Myrophis punctatus & Speckled worm eel & $0.0023(0.001)$ & $0.0004(0.0004)$ & NA 0.00 & $0(0)$ & $0(0)$ & NA \\
\hline Opsanus beta & Gulf toadfish & $0.0055(0.0045)$ & $0(0)$ & NA 0.00 & $0(0)$ & $0(0)$ & NA \\
\hline Palaemonetes pugio & Grass shrimp & $-0.0014(0.0007)$ & $0.0005(0.0004)$ & ) NA 0.00 & $0(0)$ & $0(0)$ & NA \\
\hline Panopeus herbstii & Atlantic mud crab & $0(0)$ & $0.0012(0.0012)$ & NA 0.00 & $0(0)$ & $0(0)$ & NA \\
\hline Penaeus aztecus & Brown shrimp & $0.0001(0.0001)$ & $0(0)$ & NA4.34 & $0.001(0)$ & $0(0)$ & NA \\
\hline Penaeus setiferus & White shrimp & $-0.0001(0.0001)$ & $0(0)$ & NA 4.34 & $0(0)$ & $0(0)$ & NA \\
\hline Rhithropanopeus harrisii & Harris mud crab & $0.0277(0.0057)$ & $0.023(0.0077)$ & NA 0.00 & $0(0)$ & $0(0)$ & NA \\
\hline
\end{tabular}




\section{Table 4(on next page)}

Increased nekton biomass and value

Mean ( \pm one standard error) nekton biomass $\left(\mathrm{kg} \mathrm{m}^{-2}\right)$ and value of commercial fishery $\left(\$ \mathrm{~m}^{-2}\right)$ from experimental oyster reef versus paired reference mud-bottom sites by sampling year. Overall mean ( \pm one standard error) values are presented in the last row for the entire study period. Reef cost is a one time, initial cost that requires no maintenance through time ( $L a$ Peyre et al. 2014). 
2 Table 4. Mean ( \pm one standard error) nekton biomass $\left(\mathrm{kg} \mathrm{m}^{-2}\right)$ and value of commercial fishery

$3 \quad\left(\$ \mathrm{~m}^{-2}\right)$ from experimental oyster reef versus paired reference mud-bottom sites by sampling

4 year. Overall mean ( \pm one standard error) values are presented in the last row for the entire study 5 period. Reef cost is a one time, initial cost that requires no maintenance through time (La Peyre 6 et al. 2014).

7

\begin{tabular}{|c|c|c|c|c|c|}
\hline Year & $\begin{array}{l}\text { Oyster reef nekton } \\
\text { biomass }\left(\mathbf{k g ~ m}^{-2}\right)\end{array}$ & $\begin{array}{l}\text { Mud-bottom nekton } \\
\text { biomass }\left(\mathrm{kg} \mathrm{m}^{-2}\right)\end{array}$ & $\begin{array}{c}\text { Oyster reef } \\
\text { nekton value }(\$ \\
\left.\mathbf{m}^{-2}\right)\end{array}$ & $\begin{array}{c}\text { Mud-bottom } \\
\text { nekton value (\$ } \\
\left.\mathrm{m}^{-2}\right)\end{array}$ & $\begin{array}{c}\text { Oyster reef } \\
\text { cost } \\
\left(\$ \mathrm{~m}^{-2}\right)\end{array}$ \\
\hline 1 & $0.2641(0.0323)$ & $0.1219(0.0309)$ & $0.15(0.04)$ & $0.08(0.01)$ & 105.03 \\
\hline 2 & $0.1783(0.0439)$ & $0.0715(0.0453)$ & $0.18(0.07)$ & $0.05(0.03)$ & 0 \\
\hline 3 & $0.2132(0.0183)$ & $0.0955(0.0051)$ & $0.17(0.03)$ & $0.12(0.02)$ & 0 \\
\hline Mean & $0.2185(0.0315)$ & $0.0963(0.0271)$ & $0.17(0.04)$ & $0.08(0.02)$ & 35.01 \\
\hline
\end{tabular}

8 


\section{1}

Study area map

Location of study area in Sister (Caillou) Lake, Terrebonne, Louisiana. Study regions are classified as North, West, or South. Two sites are displayed for each region, where paired oyster reef $(25 \times 1.5 \times 1 \mathrm{~m})$ and reference mud-bottom were sampled quarterly from 2009 through 2011.

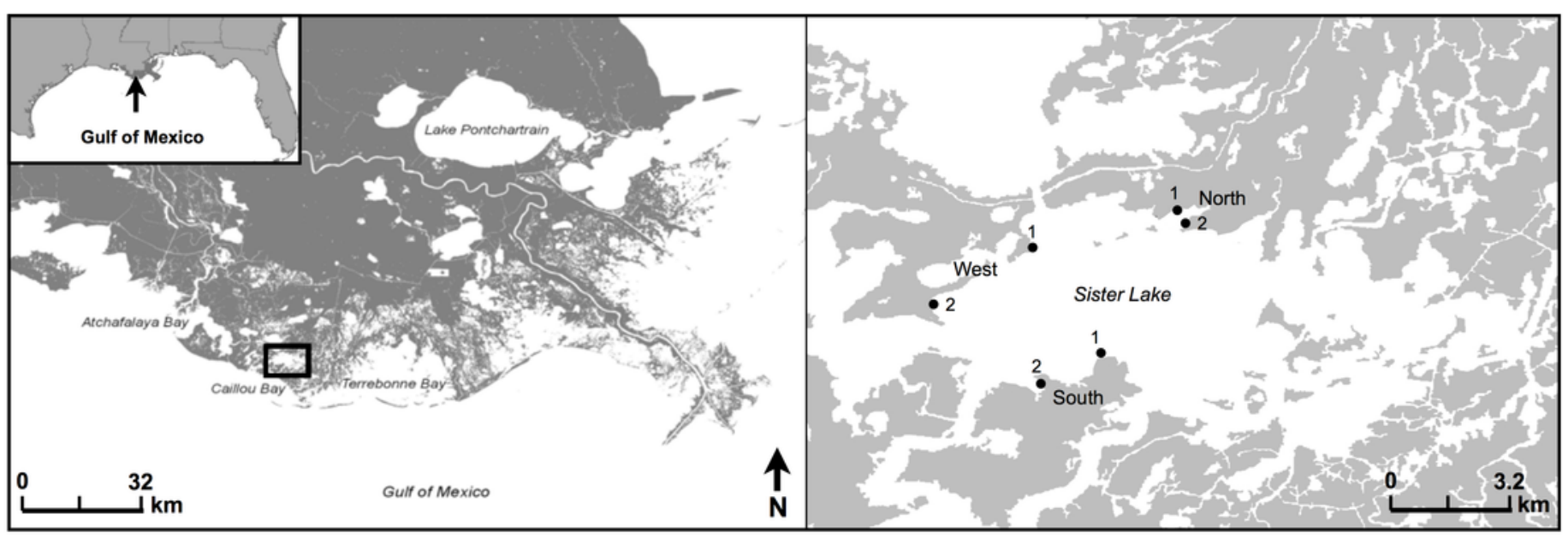


2

Total nekton biomass

Box and whisker plots of nekton biomass $\left(\mathrm{kg} \mathrm{m}^{-2}\right)$ of species caught in (A) gill net, (B) seine, and (C) tray gears at experimental oyster reef and paired reference mud-bottom sites.

Significant differences between reef and mud-bottom reference values are indicated by an asterisk $(p<0.05)$.

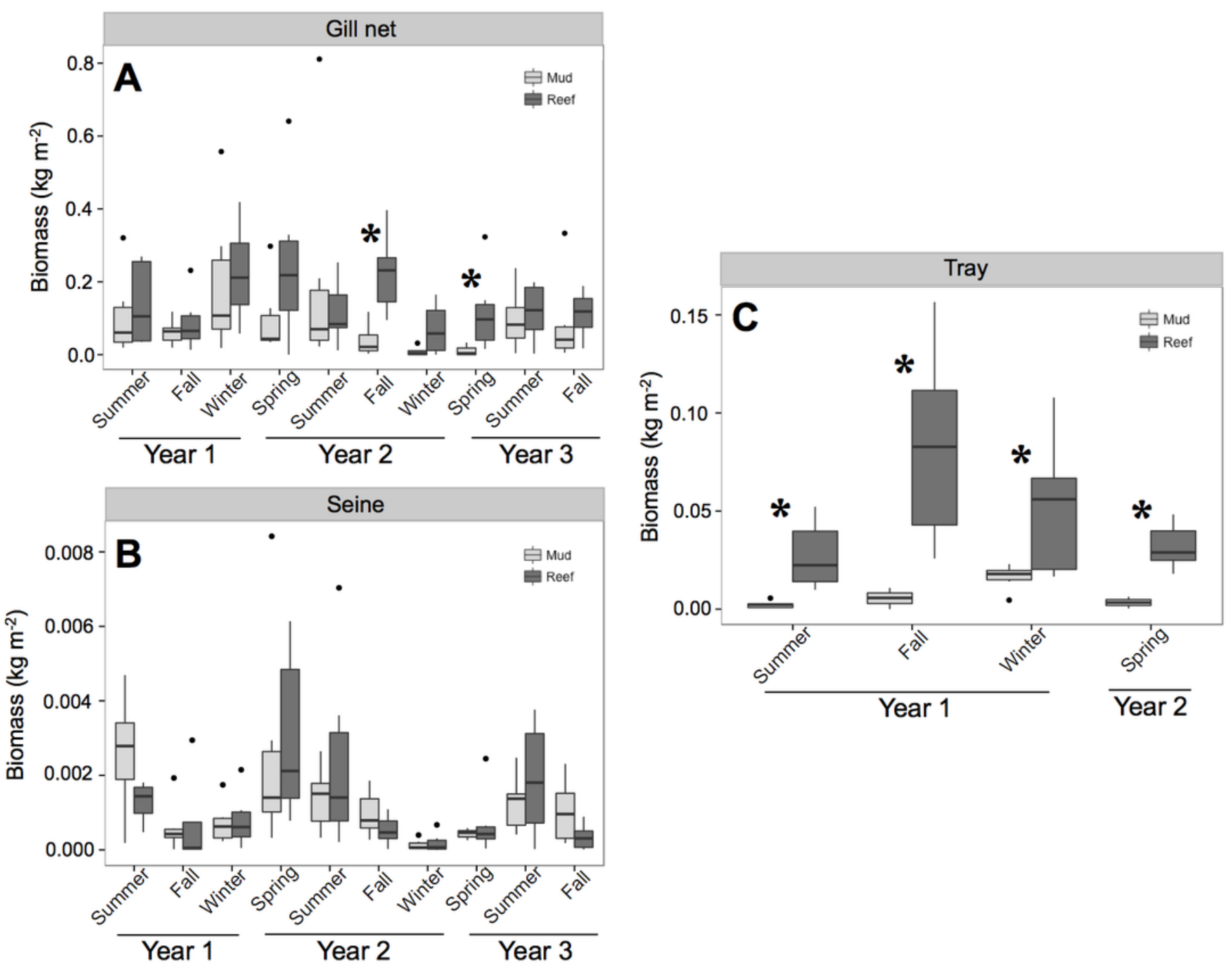


3

Nekton species biomass

Mean ( \pm one standard error) nekton biomass $\left(\mathrm{kg} \mathrm{m}^{-2}\right)$ of dominant (i.e. $>3 \%$ of total biomass) species captured with (A) gill net, (B) seine, and (C) trays at at all experimental oyster reef and paired reference mud-bottom sites. Significant differences between reef and mud-bottom reference values are indicated by an asterisk $(p<0.05)$.
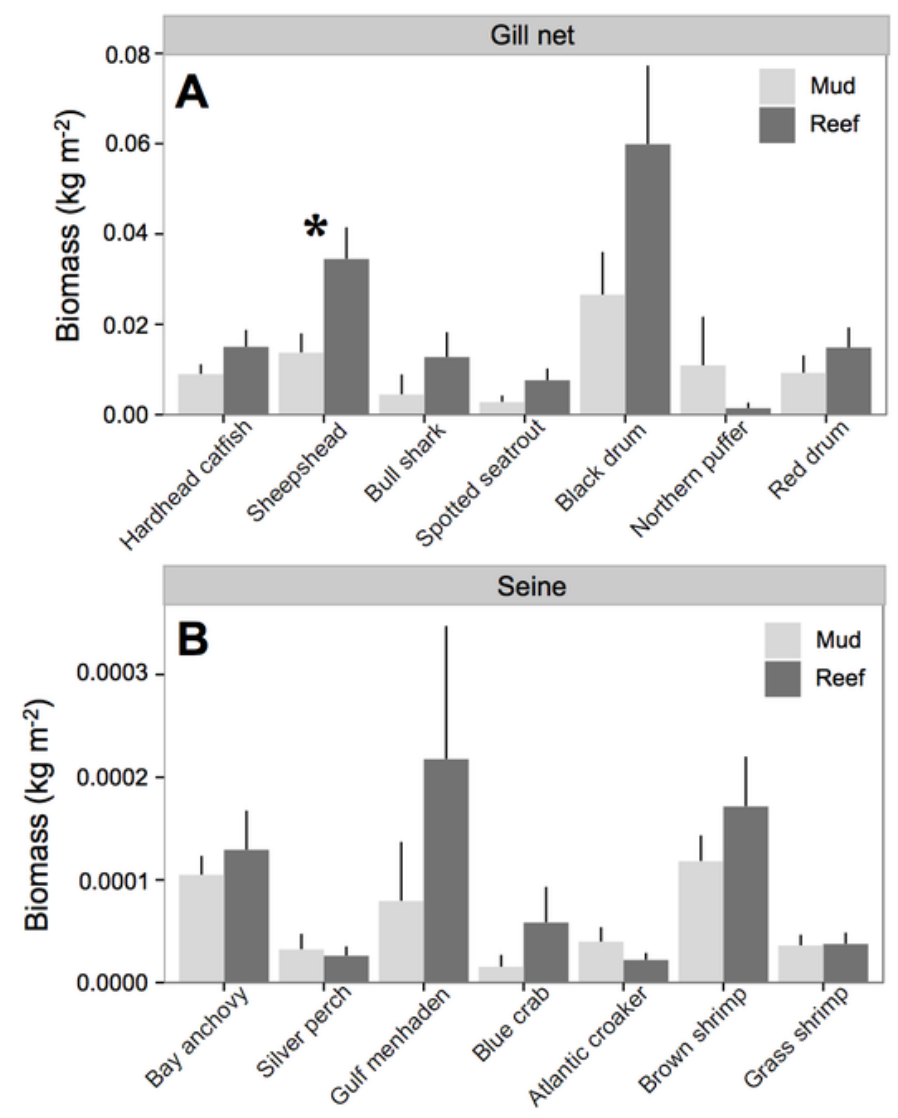

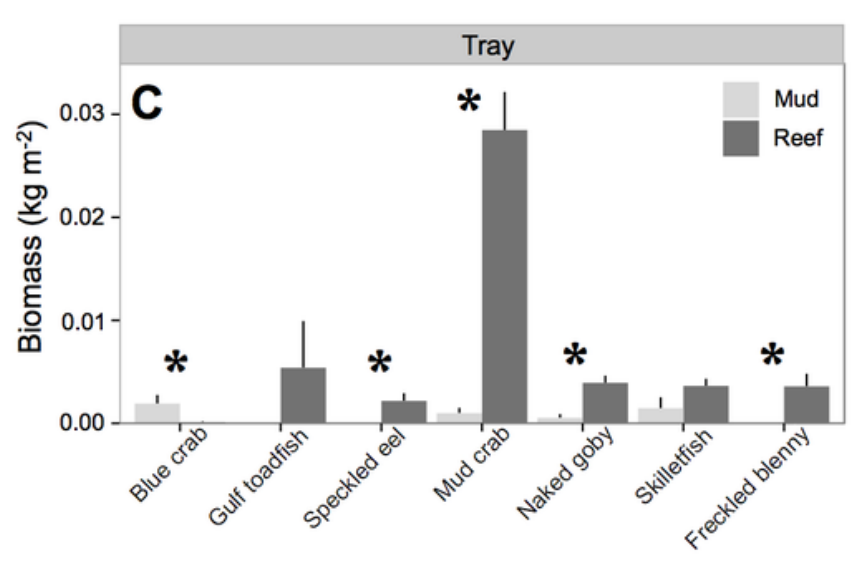


4

Increased nekton biomass and value

Mean ( \pm one standard error) of increased $(A)$ nekton biomass $\left(\mathrm{kg} \mathrm{m}^{-2}\right)$ and $(B)$ commercial fishery value ( $\$ \mathrm{~m}^{-2} ; 2011$ US dollar) of total nekton catch at all oyster reef sites as compared to reference, mud-bottom sites. Linear model results are displayed in the top corner. 

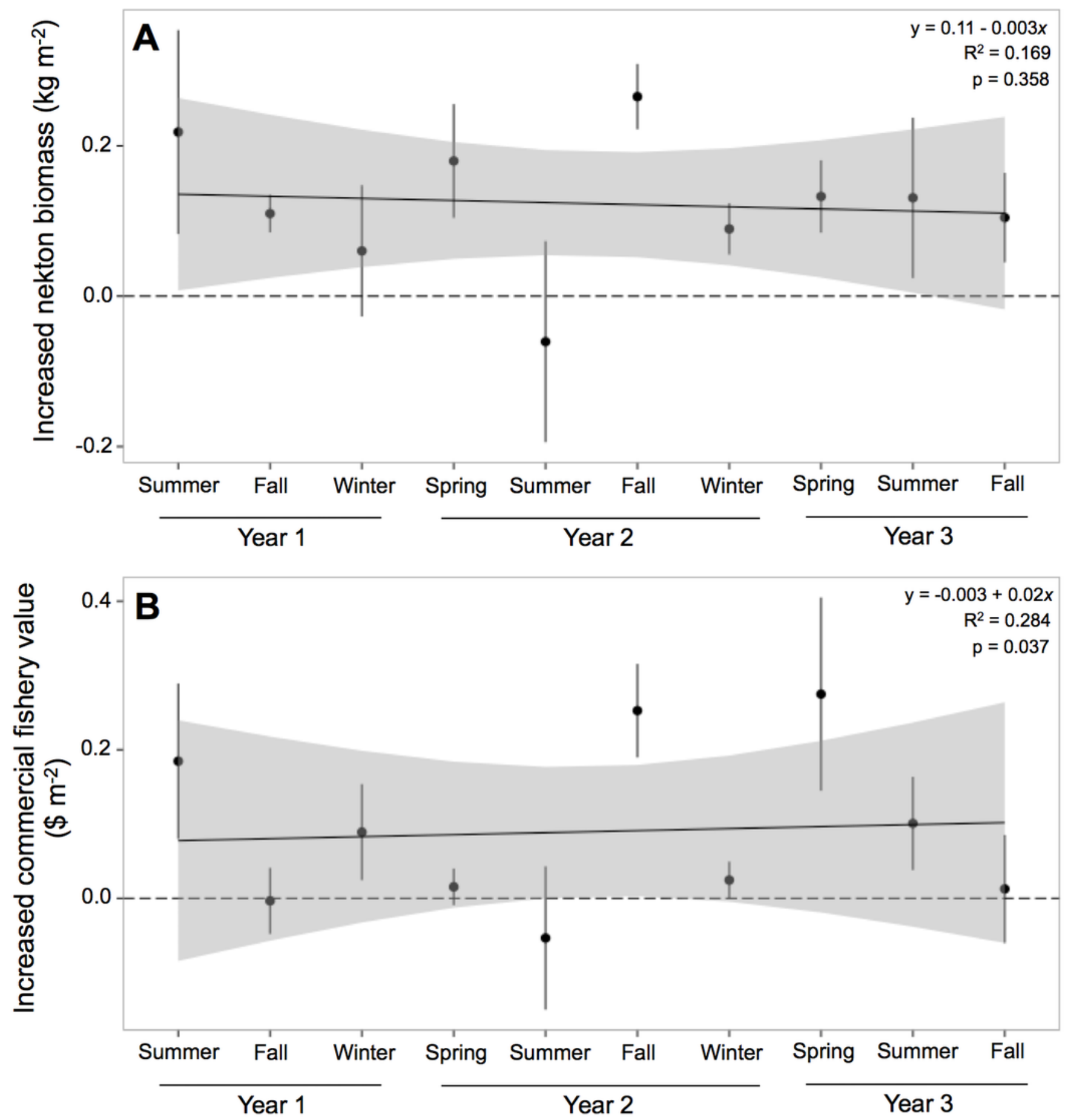